$92,8 \%$. Chỉ có 0,08 răng được hàn chiếm $0,6 \%$. Chỉ số $S M T-R$ cùng với $M-R$ tăng dần theo tuổi. Nhu cầu điều trị sâu răng trong cộng đồng chiếm tỉ lệ $32,1 \%$ với trung bình mỗi người cần điều trị 2,81 răng sâu.

\section{TÀI LIÊU THAM KHẢO}

1. Mai Hoàng Khanh (2009), Tình hình sức khỏe răng miệng và nhu câu điêu trị răng miệng ở người cao tuổi thành phố Cần Thờ. Luận văn thạc sỹ y học, Khoa Răng hàm mặt, Đại học Y Dược TP Hồ Chí Minh, 48-59.

2. Nguyễn Thị Ninh (2015), Thực trạng bệnh sâu răng ở người cao tuôi thành phố Hải P̉oong và một số yếu tố liên quan năm 2015. Luận văn thạc sỹ y hoc, Đại học Y Hà Nội, 44-51.

3. Lầm Kìm Triển (2014), Tác động của sức khỏe răng miệng lên chất lượng cuộc sống của người cao tuổi tại một số viện dưỡng lão ở TP.HCM, Luận văn thac sĩ y hoc, Đai hoc Y dươc TP.HCM , 45-52.

4. Phạm Văn Việt (2004), Nghiên cứu tình trạng, như câu chăm sóc sức khỏe răng miệng và đánh giá kết quả hai năm thực hiện nội dung chăm sóc răng miệng ban đâu ở người cao tuổi tại Hà Nội. Luân án tiến sĩ y hoc, trường Đai hoc Y Hà Nồi, 64-75்.

5. Trương Mạnh Dũng (2009), Tình trạng sâu răng ở người cao tuổi phường Nghĩa Tân, quận Cầu Giấy, thành phố Hà Nội, Đại học y Hà Nội ( Số 1), 4-5.

6. Trân Văn Trường và cs (2002), Điều tra sức khỏe răng miệng toàn quốc, Nxb Y học, 70-83.

7. Lu Liu và cs (2013), Prevalence and Correlates of Dental Caries in an Elderly Population in Northeast China, www.plosone.org.

8. Peterson P E và cs (2010), Global oral health of older people - Call for public health action, Community Dental Health, 257-268.

\title{
ĐÁNH GIÁ PHÂN BỐ CỦA 18F-SODIUM FLUORIDE TRÊN CHUộT THỰC NGHIỆM
}

\section{Nguyễn Thị Kim Dung*, Nguyễn Khắc Thất**, Phạm Đăng Tùng***, Nguyễn Quốc Thắng***, Mai Hồng Sơn*, Lê Ngọc Hà*}

\section{TÓM TẮT}

Mục tiêu: Đánh giá phân bố sinh học của ${ }^{18}$ Fluorine-Sodium fluoride ( $\left.{ }^{18} \mathrm{~F}-\mathrm{NaF}\right)$ trên chuột thực nghiệm tại Trung tâm máy gia tốc và $Y$ học hạt nhân, Bệnh viên Trung ương Quân đội 108. Đổi tượng và phương pháp: 42 chuột nhẳt trắng chủng Swiss đước nuôi trong điều kiện tiêu chuẩn của Viện Vể sinh Dịch tễ Trung ương. Chuột được chia thành 07 nhóm, được tiêm dước chất phóng xạ (DCPX) ${ }^{18} \mathrm{~F}-\mathrm{NaF}$ và mố tại các thời điểm $03,05,10,20,30,45$ và 60 phút sau khi tiêm và tỷ lệ liều tiêm/gram mô được tính toán. Kết quả: sau khi tiêm 45 và 60 phút, hoạt độ phóng xạ tập trung cao nhất trên hê thống xương ở chuột thí nghiệm với \%ID/g tương ứng là $23,62 \pm 5,58$ và $23,65 \pm 5,21$. Tương ứng với đó, tỷ số xương/cơ và xương/máu lần lượt là $16,84 \pm 5,63$ và $66,35 \pm 5,59$.

Tư khóa: đánh giá phân bố, ${ }^{18} \mathrm{~F}-\mathrm{NaF}$, động vật thực nghiệm

\section{SUMMARY \\ EVALUATION OF BIODISTRIBUTION OF

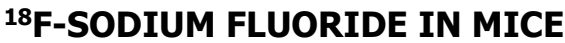

*Bẹnh viện Trung ương Quân đội 108

**Trung tâm máy gia tốc, Bệnh viện Trung ương Quân đội 108

***Đơn vị Y học hạt nhân, Bệnh viện Đa khoa Vinmec Times city

Chịu trách nhiệm chính: Nguyễn Thị Kim Dung

Email: kimdungchi@gmail.com

Ngày nhận bài: 3.3.2021

Ngày phản biện khoa học: 26.4.2021

Ngày duyệt bài: 6.5.2021
Objective: Biological distribution of ${ }^{18} \mathrm{~F}-\mathrm{NaF}$ in mice was evaluated at Center of Nuclear medicine and Cyclotron Department - 108 Military central hospital. Subject and method: 42 mice were divided into 07 groups, ${ }^{18} \mathrm{~F}-\mathrm{NaF}$ was given intravenously. Bones, blood and organs samples were collected at 03, 05, 10, 20, 30,45 and 60 minutes post-injection and percentage injected dose per gram $(\% \mathrm{ID} / \mathrm{g})$ was calculated for each sample. Results: 45 and 60 minutes after IV injection, ${ }^{18} \mathrm{~F}-\mathrm{NaF}$ radiopharmaceutical uptakes highly in the bone system of mice with $\% \mathrm{ID} / \mathrm{g}$ of $23.62 \pm$ 5.58 and $23.65 \pm 5.21$ respectively. The corresponding ratios of bone/muscle and bone/blood were $16.84 \pm 5.63$ và $66.35 \pm 5.59$ respectively.

Keywords; biodistribution evaluation, ${ }^{18} \mathrm{~F}-\mathrm{NaF}$, experimental animal.

\section{I. ĐẶT VẤN ĐỀ}

Các tổn thương lành tính như chấn thương, cốt tủy viêm, gãy xương, viêm khớp và ác tính như ung thư xương nguyên phát, di căn xương là những bệnh thường gặp trong thực hành lâm sàng. Chụp xạ hình xương toàn thân (WBS) trên máy gamma camera sử dụng dược chất phóng xạ 99mTc-MDP là một kỹ thuật y học hạt nhân kinh điển được ứng dụng để ghi hình hệ thống xương [1]. Tuy nhiên, nhược điểm của phương pháp này là độ phân giải không gian thấp, độ nhạy của phương pháp thấp đối với tổn thương dạng huỷ xương. PET/CT sử dụng ${ }^{18} \mathrm{~F}$-Sodium fluoride $\left({ }^{18} \mathrm{~F}-\mathrm{NaF} \mathrm{PET} / \mathrm{CT}\right)$ cho phép chụp cắt lớp toàn thân với độ phân giải và chất lượng hình ảnh cao hơn so với xạ hình xương thông thường. 
Sự kết hợp hình ảnh về cấu trúc trên chụp cắt lớp vi tính (Computed Tomography) và hình ảnh chuyển hoá trên PET (Positron Emission Tomography) có thể cho phép PET/CT phát hiện sớm và chính xác các tổn thương. Chính vì vậy, hình ảnh ${ }^{18} \mathrm{~F}-\mathrm{NaF} \mathrm{PET} / \mathrm{CT}$ hứa hẹn là một phương pháp có độ nhạy và độ đặc hiệu cao trong chẩn đoán các tổn thương xương [2], [3]. Trong vài năm gần đây, các máy cyclotron được lắp đặt và đi vào sử dụng ở Việt Nam cho phép sản xuất và điều chế phát triển các dược chất phóng xạ (DCPX) gắn ${ }^{18} \mathrm{~F}$, trong đó có ${ }^{18} \mathrm{~F}-\mathrm{NaF}$. Từ 2016, Trung tâm máy gia tốc, Bệnh viện TƯĐ 108 đã thiết kế được module tổng hợp và điêu chế thành công ${ }^{18} \mathrm{~F}-\mathrm{NaF}$ lần đầu tiên ở Việt Nam. Bên cạnh việc phân tích, kiểm nghiệm các đặc tính lý hoá và phóng xạ của ${ }^{18} \mathrm{~F}-\mathrm{NaF}$ sau khi được tổng hợp, DCPX còn cần được đánh giá phẩn bố thử nghiệm trước khi đưa vào thực hành lâm sàng. Do đó, chúng tối tiến hành nghiên cứu này để đánh giá phân bố của ${ }^{18} \mathrm{~F}-\mathrm{NaF}$ trên hình ảnh PET/CT động vật.

\section{II. ĐỐI TƯợNG VÀ PHƯƠNG PHÁP NGHIÊN CỨU}

Dược chất phóng xạ ${ }^{18} \mathrm{~F}-\mathrm{NaF}$

Dược chất phóng xạ ${ }^{18} \mathrm{~F}-\mathrm{NaF}$ được sản xuất từ máy gia tốc vòng 30 Mev (cyclotron $30 \mathrm{Mev}$ ) và module tổng hợp tại Trung tâm máy gia tốc, Bệnh viện Trung ương Quân đội 108, đạt tiêu chuẩn kiểm nghiệm theo Dược điển Anh.

Chuột thí nghiệm. 42 chuột nhắt trắng chủng Swiss, cân nặng $25 \mathrm{~g} \pm 2 \mathrm{~g}$, khỏe mạnh, được cung cấp bởi Viện Vệ sinh Dịch tễ Trung ương. Chuột thí nghiệm được nuôi trong điều kiện phòng sạch, nhiệt độ phòng được duy trì 28 $\pm 0,5^{\circ} \mathrm{C}$, độ ẩm khoảng $55 \pm 5 \%$, ánh sáng được tự động điều khiển theo chu kỳ 12 giờ sáng/12 giờ tối. Chuột được cung cấp đầy đủ thức ăn tiêu chuẩn và nước uống sạch theo nhu câu. Chuột được nuôi và làm quen với môi trường mới 03 ngày trước khi làm thí nghiệm. Chuột được chăm sóc và nuôi dưỡng theo các quy định của dược điển Việt Nam IV.

Hóa chất và thiết bị. Dịch truyền Natri chloride 0,9\%, Propofol-Lipuro $1 \%$ B. Braun Melsungen AG. Cân phân tích Robecvan, máy đo hoạt độ phóng xạ IBA, máy đếm phổ phóng xạ Canbera. Hệ thống máy PET/CT Light Speed GE.

\section{Phương pháp nghiên cứu}

Thí nghiệm được tiến hành trên chuột thực nghiệm bằng cách tiêm vào tĩnh mạch đuôi chuột dược chất phóng xạ ${ }^{18} \mathrm{~F}-\mathrm{NaF}$ và tiến hành mổ chuột tại các thời điểm 03 phút; 05 phút; 10 phút; 20 phút; 30 phút; 45 phút; 60 phút sau khi tiêm để lấy mẫu là các nội tạng của chuột và tiến hành đo hoạt độ phóng xạ các mẫu trên máy đo đếm phổ phóng xạ. Chuẩn bị liều tiêm cho mỗi động vật là $0,2 \pm 0,02 \mathrm{mCi}{ }^{18} \mathrm{~F}-\mathrm{NaF}$. Hoạt độ phóng xạ trong mô hoặc cơ quan trên gam $(\% \mathrm{ID} / \mathrm{g})$ : được tính bằng cách lấy phần trăm hoạt độ phóng xạ của từng mô (\%ID) chia cho trọng lượng cân được của mô đó [4].

$\% \mathrm{ID} / \mathrm{g}=(\% \mathrm{ID}) /($ Khối lượng của mô hoặc cơ quan)

Trong đó khối lượng các mô và cơ quan chuột được tính bằng cách lấy khối lượng ống đựng mẫu trừ đi khối lượng ống. Khối lượng máu của mỗi con chuột được tính bằng $7 \%$ trọng lượng cơ thể chuột [9]. Liều tiêm và hoạt độ được hiệu chỉnh suy giảm theo thời gian. Tổng hoạt độ phóng xạ tiêm vào cơ thể chuột được tính bằng cách lấy tổng hoạt độ phóng xạ trong bơm tiêm trước khi tiêm trừ đi hoạt độ dư còn dư lại trên bơm tiêm sau tiêm và hoạt độ phần đuôi $(\mathrm{kGq})$.

Xử lý số liệu. Các số liệu được thu thập bằng phần mềm Microsoft Office Excel 2010. Phân tích thống kê được thực hiện bằng phần mềm SPSS 20.0 (Chicago, Inc.). So sánh các biến định lượng được biểu hiện dưới dạng số trung bình X (mean) \pm độ lệch chuẩn (SD) hoặc tỷ lệ phần trăm. Sử dụng T-test student để so sánh các giá trị trung bình giữa các nhóm với sự khác biệt là có ý nghĩa thống kê khi $p<0,05$.

\section{KẾT QUẢ NGHIÊN CứU}

Hoat độ phóng xa ${ }^{18} \mathrm{~F}-\mathrm{NaF}$ ở xương và một số cơ quan khác trên chuột thực nghiệm được đánh giá tại các thời điểm 03 phút; 05 phút; 10 phút; 20 phút; 30 phút; 45 phút và 60 phút sau khi tiêm dược chất phóng xạ ${ }^{18} \mathrm{~F}-\mathrm{NaF}$.

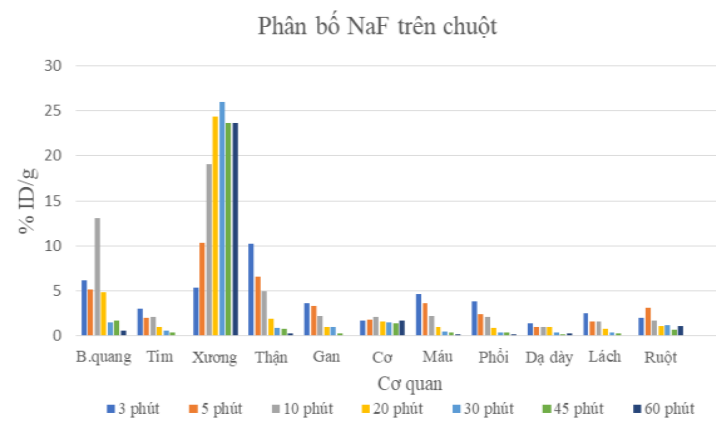

Hình 1. Hoạt độ phóng xạ và sự thay đổi theo thời gian ở các mô, cơ quan động vật thức nghiêm $(n=42)$

Hoạt độ phóng xạ đo được ở máu cao nhất sau tiểm 03 phút $(4,67 \pm 0,91)$ và giảm rõ rệt theo thời gian. Ở phút thứ 60 sau tiêm DCPX ${ }^{18} \mathrm{~F}$ - 
NaF, hoat đô phóng xa đo đướ tai máu còn rất thấp $(0,22 \pm 0,15)$. Trong giai đoạn bể máu (blood pool) thời điểm 03 phút sau tiêm DCPX, hoạt độ phóng xạ tại các mô và cơ quan là cao nhất, sau đó giảm dần theo thời gian. Hoạt độ phóng xạ tại thận cao ở những phút đầu (03 đến 20 phút) và giảm dần theo thời gian. Hoạt độ phóng xạ ở nước tiểu tại bàng quang rất cao tại những phút đầu và trong cả quá trình theo dõ̃i đến phút thứ 60 . Hoạt độ phóng xa đo được ở xương tại phút thứ 30 là cao nhất với giá trị trung bình $\% \mathrm{ID} / \mathrm{g}$ là $25,97 \pm 7,04$. Hoạt độ phóng xa trung bình ở phút thứ 45 và 60 (tương ứng $23,62 \pm 5,58$ và $23,65 \pm 5,21$ ) có xu hướng giảm so với ở thời điểm phút thứ 30 nhưng chưa có sự khác biệt có ý nghĩa thống kê ( $p>0,05)$.

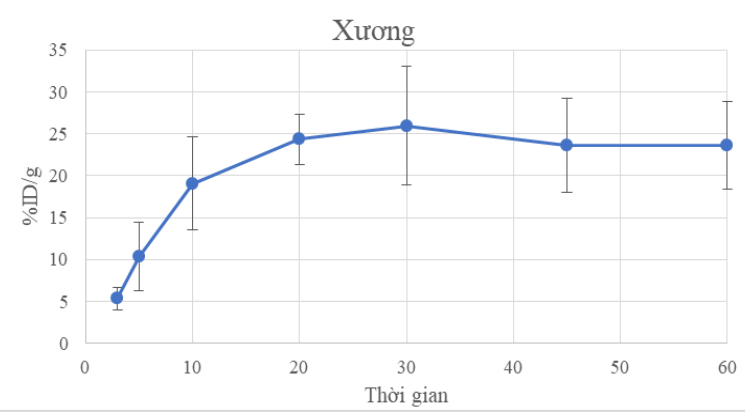

Hình 2. Sư biến đôî về \%ID/gtrung bình ơ xưong theo thời gian $(n=42)$

Hình ảnh ${ }^{18} \mathrm{~F}-\mathrm{NaF} \mathrm{PET}$ có độ tương phản, sắc nét khi tỷ lệ hoạt độ phóng xạ giữa xương với cơ và máu cao.

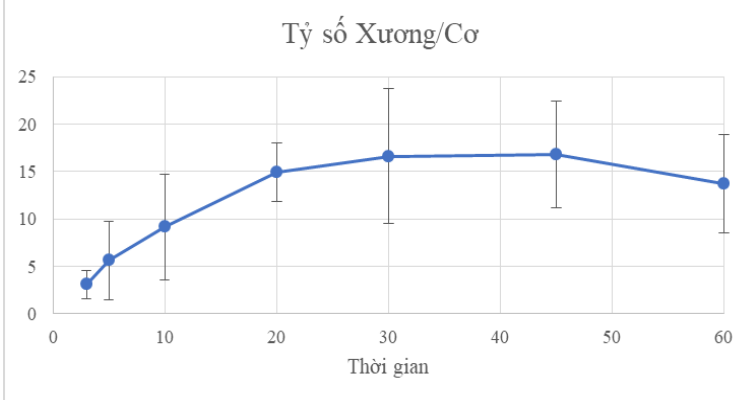

Tỷ số Xương/máu

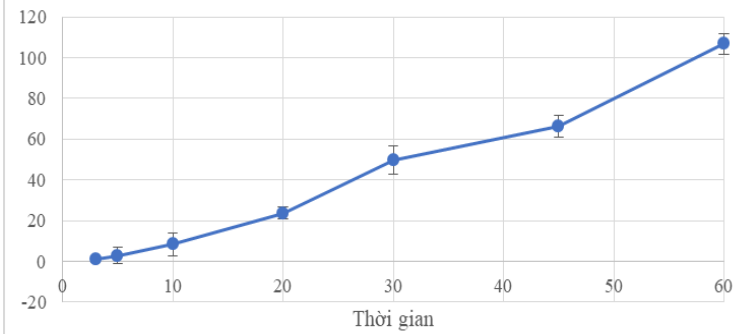

Hình 3. Sự thay đổi tỷ lệ hoạt độ phóng xạ

\section{của xương/cơ và xương/máu theo thời gian $(n=42)$}

Giá trị \%ID/g của cơ cao nhất tại thời điểm 10 phút sau khi tiêm với giá trị 2,08 $\pm 0,72$, trong khi đó hoat đô phóng xa tấp trung ở máu cao nhất ngay tại thời điểm 03 phút sau khi tiêm với $\% \mathrm{ID} / \mathrm{g}$ là $4,67 \pm 0,91$. Tỷ lệ hoạt độ phóng xa ở xương/cơ thấp nhất ở phút thứ 03 , sau đó tăng dần và đat được ngưỡng cao nhất đạt được ở phút thứ 45 . Sau đó, tỷ lệ này có xu hướng giảm ở phút thứ 60 . Trái lại, tỷ lệ hoạt độ phóng xạ của xương/máu tăng trong suốt các thời điểm khảo sát.

Ở các mô và cơ quan khác bao gồm tim, phổi, dạ dày, gan, lách hoạt độ phóng xạ đều có xu hướng giảm dần theo thời gian và thấp hơn nhiều so với hoạt độ phóng xạ ở xương ( $p$ < $0,01)$, tương ứng với quá trình đào thải thuốc khỏi cơ thể.

\section{BÀN LUÂN}

Môt số nghiên cứu về cơ chế hấp thu và phân bố của ${ }^{18} \mathrm{~F}-\mathrm{NaF}$ đã cho thây sau khi tiêm tĩnh mạch, F-18 nhanh chóng được thải trừ khỏi huyết tương theo hàm mũ với giai đoạn đầu tiên có thời gian bán hủy 0,4 giờ và pha thứ hai có thời gian bán hủy 2,6 giờ [5]. F-18 khuếch tán qua các mao mạch quanh tố chức xương và đi vào dịch khoang ngoại bào ngoài xương và xảy ra sư tích tu hóa hoc ở bề mặt của các tinh thể xương. Đặc biệt, các vị trí của xương đang phát triển được khoáng hóa sự tích tụ xảy ra mạnh hơn. Về cơ bản, toàn bộ $\mathrm{F}-18$ được chuyển đến xương theo đường máu đước giữ lai trong xương. Một giờ sau khi tiêm F-18 chỉ có khoảng $10 \%$ liêu tiêm vào trong máu theo dược điển Hoa Kỳ (USP 32). Kết quả nghiên cứu của chúng tôi trên chuôt cho thấy dược chất phóng xa ${ }^{18} \mathrm{~F}$ NaF phân bố cao trong máu ngay sau khi tiêm với hoạt độ phóng xạ trong máu đo được cao nhất ở phút thứ 3 là 4,67 $\pm 0,91$ và giảm rõ rệt theo thời gian tai các thời điểm tiếp theo 05,10 , 20,30 và 45 phút $(p<0,05)$. Ở phút thứ 60 sau tiêm $\mathrm{DCPX}{ }^{18} \mathrm{~F}-\mathrm{NaF}$, hoạt độ phóng xạ tại máu chỉ còn $0,22 \pm 0,15$ (hình 1). Cũng như các DCPX sử dung trong chup xa hình xương khác, ${ }^{18} \mathrm{~F}-\mathrm{NaF}$ được đào thải qua thận. Kết quả nghiên cứu của chúng tôi cho thấy hoạt độ phóng xạ tại thận cao ở những phút đầu (03 đển 10 phút) và giảm dần theo thời gian. Tuy nhiên, hoạt độ phóng xa tai bàng quang thay đổi không theo quy luật có thể do quá trình thực nghiệm lượng nước tiểu trong bàng quang của mối chuột là khác nhau. Nghiên cứu của Blake GM và cộng sự 
(2001) đã cho thấy độ thanh thải ${ }^{18} \mathrm{~F}-\mathrm{NaF}$ phụ thuộc vào lưu lượng nước tiểu [5]. Khi lưu lượng nước tiểu cao ( $\geq 5 \mathrm{ml} /$ phút), độ thanh thải ion Fluoride -18 chiếm từ $60-90 \%$ của độ lọc câu thận. Tuy nhiên, với lưu lượng thấp <1 mi/phút, độ thanh thải thận chỉ đạt khoảng 5\% độ lọc câu thận. Trên thực hành lâm sàng khi tiến hành chụp xạ hình xương, sau tiêm DCPX, bệnh nhân cân được uống nhiều nước để tăng lượng nước tiểu và đào thải dược chất phóng xạ, giảm liêu chiếu xạ, tăng tỷ lệ bắt giữ phóng xạ ở hệ thống xương so với phông phóng xạ của cớ thể [6].

\section{KẾT LUẬN}

Như vậy, kết quả nghiên cứu của chúng tôi cho thây ngay sau khi tiêm ${ }^{18} \mathrm{~F}-\mathrm{NaF}$, DCPX tăng cao ở máu và các tổ chức ngoài xương và giảm nhanh. Trái lại, ${ }^{18} \mathrm{~F}-\mathrm{NaF}$ hấp thu nhanh vào xương, nông độ ${ }^{18} \mathrm{~F}-\mathrm{NaF}$ tăng nhanh sau khi tiêm và đạt cực đại tại thời điểm 30 phút và giảm không đáng kể ở các thời điểm 45 và 60 phút.

\section{TÀI LIÊU THAM KHẢO}

1. S. G.B., Fundamentals of Nuclear Pharmacy.
Fourth ed., New York: Springer , 2016.

2. Bastawrous S., Bhargava P., Behnia F., Djang D.S.W., Haseley D.R., «Newer PET Application with an Old Tracer: Role of $18 \mathrm{~F}-\mathrm{NaF}$ Skeletal PET/CT in Oncologic Practice,» RadioGraphics, vol. 34, pp. 1295-1316, 2014.

3. Even-Sapir E., Mishani E., Flusser G., Metser U., editors., «18 F-Fluoride positron emission tomography and positron emission tomography/computed tomography.,» Seminars in nuclear medicine, 2007.

4. e. a. Silveira M.B., "Synthesis, quality control and dosimetry of the radiopharmaceutical $18 \mathrm{~F}-$ sodium fluoride produced at the Center for Development of Nuclear Technology-CDTN,》 Brazilian Journal of Pharmaceutical Sciences, vol. 46, pp. 563-9., 2010.

5. Peters M.J., Wierts R., Jutten E.M., Halders S.G., Willems P.C., Brans B. , «Evaluation of a short dynamic 18F-fluoride PET/CT scanning method to assess bone metabolic activity in spinal orthopedics, $\gg$ Annals of nuclear medicine, vol. 29, pp. 799-809, 2015.

6. Blake G.M., Park-Holohan S.J., Cook G.J., Fogelman I., «Quantitative studies of bone with the use of 18 F-fluoride and $99 \mathrm{mTc}$-methylene diphosphonate,» Semin Nucl Med, vol. 31, p. 280 49, 2001.

\title{
ỨNG DƯNG KỸ THUÂTT LẤY HUYẾT KHỐI BẰNG DƯNG CƯ CƠ HỌC SOLITAIRE Ở BỆNH NHÂN NHỒI MÁU NÃO CẤP DO TẮC MẠCH MÁU LỚN TẠI BVĐK TỈNH THANH HÓA
}

\author{
Hoàng Hũu Trường*, Phạm Phước Sung*, Nguyễn Hoành Sâm*, \\ Lường Hữu Dương*, Đoàn Thị Bích*, Lê Hồng Ninh*, \\ Nguyễn Văn Hà*, Nguyễn Trường Giang*.
}

\section{TÓM TẮT}

Mục tiêu: (1) Đánh giá kết quả điều trị can thiệp lấy huyết khối bằng dụng cụ cơ học Solitaire ở bệnh nhân nhồi máu não tối cấp. (2)Tìm yếu tố liên quan đến tiên lượng kết cục phục hồi chức năng thần kinh tại sau 3 tháng can thiệp. Phương pháp: Nghiên cứu mô tả, tiến cứu loạt 35 trường hợp nhồi máu não tối cấp, trong vòng 6 giờ từ khi khởi phát, điều trị bằng phương pháp lấy huyết khối bằng dụng cụ cơ học Solitaire, tại khoa Thần kinh - Đột quỵ, Bệnh viện Đa khoa tỉnh Thanh Hóa từ tháng 4/2019 đến tháng 4/ 2020. Kết quả: Tuổi trung bình $64.57 \pm 10.20$, tỷ lệ nam/nữ 1/1.06, điểm NIHSS trung bình lúc vào viện $13,22 \pm 5,38$ điểm, trung vị 13 điểm; tăng huyết áp $71.43 \%$, đái tháo đường $25.71 \%$, xơ vữa động mạch

*Bênh viên Đa khoa Tỉnh Thanh Hóa

Chịu trách nhiệm chính: Phạm Phước Sung

Email: bsphamsung@gmail.com

Ngày nhận bài: 4.3.2021

Ngày phản biên khoa học: 22.4.2021

Ngày duyệt bài: 4.5.2021 lớn $54.29 \%$, rung nhĩ $34.29 \%$, suy tim 20\%, bệnh lý van tim $17.14 \%$. Điểm trung vị các thang điểm tiên lượng: ASPECT, HAT, DRAGON, ASTRAL lần lượt là 7 , 1, 5, 25 điểm. Dấu hiệu tăng tỷ trọng động mạch não giữa đoạn $M 1$ trên chụp cắt lớp vi tính (CT) chiếm 37.14\%. Tắc đông mach cảnh trong kết hợp M1 động mạch não giữa chiếm $28.57 \%$, tắc động mạch não giữa đơn thuần chiếm $62.86 \%$, tắc động mạch thân nền chiếm $8.57 \%$. Nguyên nhân bệnh mach máu lớn chiếm $51.42 \%$, huyết khối từ tim chiểm $34.29 \%$, nguyên nhân không xác định chiếm $14.29 \%$. Tái thông hoàn toàn (TICI 3) chiếm $42.86 \%$, TICI 2b $17.14 \%$, TICI $2 \mathrm{a} 20 \%$. Xuất huyết não có triệu chứng chiếm $8.57 \%$, phục hồi chức năng thần kinh tốt sau 3 tháng (mRS $0-2$ ) chiếm $34.29 \%$, tử vong sau 3 tháng chiếm $14.29 \%$. Kết luận: Can thiêp lấy huyết khối đường động mạch bằng dụng cụ cơ học Solitaire cho loạt 35 bệnh nhân đột quỵ nhồi máu não tối cấp cửa sổ điều trị dưới 6 giờ, cho thấy thành công về mặt kỹ thuật. Tỷ lệ có tái thông cao (94.29\%), trong đó tái thông hoàn toàn đạt $42.86 \%$. Tỷ lệ xuất huyết não có triệu chứng chiếm $8.57 \%$. Mức độ hồi phục chức năng thần kinh tốt (mRS $0-2)$ tại thời điểm 3 tháng 